\title{
EXPRESSION OF SELECTED CANDIDATE GENES DURING DIFFERENT STAGES OF CORPUS LUTEUM DEVELOPMENT IN CYCLIC EGYPTIAN BUFFALOES
}

Marwa S. Faheem ${ }^{1,2}$ and Sh. M. Dessouki ${ }^{1,2}$

1- Department of Animal Production, Faculty of Agriculture, Cairo University, Giza, Egypt, 2- Cairo University Research Park (CURP), Faculty of Agriculture, Cairo University, Giza, Egypt

Received: $16 / 6 / 2019$

Accepted: 27/6/2019

\section{SUMMARY}

The current study was done to investigate the expression profile of selected candidate genes in corpus luteum of cyclic Egyptian buffaloes. A total number of nine corpora lutea (CLs) was collected from 9 cyclic slaughtered female Egyptian buffaloes. Based on their developmental phases and morphological features, CLs were classified into; growing (around days 3-5), static (around days 7-10) and regressed (around days 19-21 of the estrous cycle). Transcript abundance of genes regulating mitochondrial activity (SOD2, TFAM and CPT2), lipid metabolism (SREBP1), pro-inflammatory cytokine (TNF $\alpha$ ) and oxidative stress (NFE2L2) was assessed relative to GAPDH as a housekeeping gene.

Relative gene expression profiles of TFAM and SOD2 increased $(P \leq 0.05)$ in static phase compared to both growing and regressed phases. Transcript abundance of both CPT2 and SREBP1 was significantly higher at static phase, while was at minimum level of expression during regression phase. The expression profile of NFE2L2 revealed insignificant differences among the studied phases of CLs. Relative transcript abundance of $T N F \alpha$ was higher $(P \leq 0.05)$ at regression phase compared to growing and static ones. Taken together, the pattern of genes regulating mitochondrial activity and lipid metabolism were higher during growing phase and reached a plateau in static phase and fully declined during regression phase. Meanwhile, the transcript abundance of pro-inflammatory cytokine gene denoted an opposite trend. Thus, gene expression profile reflected the cyclic changes of buffalo corpus luteum development.

Keywords: Corpus luteum, gene expression, mitochondrial activity, buffalo.

\section{INTRODUCTION}

Corpus luteum (CL) is an ovarian structure that formed from the ovulated Graafian follicle. It has distinct morphological and physiological changes during the estrous cycle of female farm animals. The appropriate functionality of $\mathrm{CL}$ is crucial for pregnancy maintenance and normal reproductive cyclicity of the cows (Quintal-Franco et al., 1999). Different studies have been conducted to understand the developmental changes as well as progesterone profile (Barkawi et al., 2002) during estrous cycle of buffaloes.

Early study on buffaloes reported that luteal tissue has been detected as hypoechoic patches inside the developed echogenic mass on days 3-6 of the buffaloes estrous cycle (Fadel, 2000). The mean diameter of the CL when detected on day 3 was reported to be $2.8 \mathrm{~mm}, 9.3 \mathrm{~mm}$ in mature phase (about day 12), and $5.0 \mathrm{~mm}$ in diameter on day 18 (Fadel, 2000 and Barkawi et al., 2002). The duration of CL development phases was 6.4, 11 and 4.5 days for growth, static and regression while, the diameter at these phases was 2.8, 9.3 and $5.0 \mathrm{~mm}$ (Fadel, 2000 and Barkawi et al., 2002). The day at which reached that diameter was around day 10 of the estrous cycle (Barkawi et al., 2002).
These anatomical changes were also accompanied with cellular and biological activities. Jainudeen and Hafez (1993) reported that, progesterone $\left(\mathrm{P}_{4}\right)$ levels in plasma and milk of buffaloes, as in cattle, reflect the endocrine activity of CL but with lower levels than in cattle. The maximum level of plasma $\mathrm{P}_{4}$ was associated with higher number of small luteal cells (SLC) and large luteal cells (LLC) present in the CL and positively correlated with the luteal $\mathrm{P}_{4}$ production at mid-luteal (ML) stage in buffaloes (Mishra et al., 2018). CL has distinctive types of cells (O'Shea et al., 1989), which classified as steroidogenic (small and large luteal cells) and non-steroidogenic (pericytes, fibroblasts, endothelial, macrophages, leukocytes and mast cells). Overall, there have been many studies done describing the physiological and cellular changes of CL during estrous cycle of different farm animal species. However, few investigations were done to detect developmental stages of buffalo CL at the molecular level. Therefore, the current study was performed to monitor gene expression profile during different developmental phases of cyclic Egyptian buffaloes.

\section{MATERIALS AND METHODS}

Unless stated, all chemicals were purchased from Sigma-Aldrich (St. Louis, MO, USA). 


\section{Collection of CL samples:}

Ovaries were collected from local slaughterhouse immediately after slaughtering. Three different developmental stages of CL: corpus hemorrhagicum: growth phase (around days 3-5), static phase (around days 7-10) and corpus albicans: regression phase (around days 19-21), were collected and classified according to their morphological features, color and size (Ireland et al., 1980 and Ambrose et al. 1993). From each developmental stage of CL, three samples were collected from three different animals.

\section{RNA extraction:}

The total RNA was extracted from all stages of corpus luteum samples using RNA isolation kit (Qiagen, Hilden, Germany). All steps of extraction were done at room temperature. A total of $30 \mathrm{mg}$ of frozen CL tissue was grinded using a mortar pestle and homogenized thoroughly in $300 \mu \mathrm{l}$ of lysis buffer, supplemented with $10 \mu \mathrm{l}$ of $\beta$-mecaproethanol using conventional rotor-stator homogenizer for 10 sec. Afterwards, $600 \mu \mathrm{l}$ of Proteinase K $(10 \mu \mathrm{L}$ of the included Proteinase $\mathrm{K}$ diluted in $590 \mu \mathrm{L}$ of $\mathrm{TE}$ buffer) was added to lysate and mixed thoroughly by vortex then incubated for $10 \mathrm{~min}$. The whole mix was centrifuged for $5 \mathrm{~min}$ at $\geq 12000 \times \mathrm{g}$ and the supernatant was transferred into a new RNase-free micro-centrifuge tube, $450 \mu \mathrm{L}$ of ethanol (96-100\%) was added and mixed by pipetting. The lysate (700 $\mu \mathrm{L})$ was transferred to the GeneJET RNA purification column (GeneJET RNA Purification Kit, Thermofisher Scientific, CA, USA) and centrifuged for $1 \mathrm{~min}$ at $\geq 12000 \times \mathrm{g}$ and the flow-through was discard and this step for the rest of lysate was repeated. The GeneJET RNA purification column was placed into a new $2 \mathrm{~mL}$ collection tube, $700 \mu \mathrm{L}$ of wash buffer 1 was added to column, centrifuged for 1 min at $\geq 12000 \times \mathrm{g}$. Th flow-through was discarded and this step was repeated using $250 \mu \mathrm{L}$ of Wash Buffer 2. The collection tube containing the flowthrough was discarded and column was transferred to a sterile $1.5 \mathrm{~mL}$ RNase-free micro-centrifuge tube. Finally, $50 \mu \mathrm{L}$ of nuclease-free water was applied to the center of the column membrane and centrifuged for 1 min at $\geq 12000 \times \mathrm{g}$ to elute RNA, which was stored at $-80^{\circ} \mathrm{C}$ until use. The concentration of RNA was measured using a Nano Drop 2000C (Thermo Scientific, Wilmington, DC, USA). An absorbance ratio of 1.8 to 2.0 was obtained for all samples, which indicated the high purity of RNA and free from DNA contamination.

\section{cDNA synthesis}

After adjusting RNA concentration of all samples $(1 \mu \mathrm{g})$, cDNA synthesis was performed using $2 \mu \mathrm{l} 10 \mathrm{X}$ RT random primer, $2 \mu 1$ 10X RT buffer, $0.8 \mu \mathrm{l} 25 \mathrm{X}$ $\mathrm{dNTP}, 1 \mu \mathrm{l}$ multiscribe reverse transcriptase, $1 \mu \mathrm{l}$ RNase inhibitor (Applied Biosystems, USA) and various volumes of nuclease free water to make $20 \mu \mathrm{l}$ total volume. The following PCR program $\left(25^{\circ} \mathrm{C}\right.$ for $10 \mathrm{~min}, 37^{\circ} \mathrm{C}$ for $120 \mathrm{~min}$ and $85^{\circ} \mathrm{C}$ for $5 \mathrm{~min}$ ) was used for cDNA synthesis

\section{Quantitative real-time PCR analysis:}

In order to perform the relative quantification of gene expression, specific primers of target genes were designed using Prime3 software as shown in Table (1) and according to Rozen and Skaletsky (2000) from sequences described in the GenBank database (www.ncbi.nlm.nih.gov). Quantitative analysis of cDNA samples was performed using a StepOnePlus ${ }^{\mathrm{TM}}$ Real-Time PCR instrument (Applied Biosystems, USA). Prior to quantification, the forward and reverse primers were optimized. Specific primer combinations with low threshold cycle (CT) values and that did not form primer dimers were selected for subsequent PCR. PCR was performed in a $20 \mathrm{uL}$ reaction volume containing $10 \mathrm{uL}$ of Power SYBR Green PCR Master Mix (Applied Biosystem). Universal thermal cycling parameters $(10$ minutes at $95{ }^{\circ} \mathrm{C}$, then 40 cycles of 15 seconds at $95{ }^{\circ} \mathrm{C}, 20$ seconds at $60{ }^{\circ} \mathrm{C}$, and 30 seconds at $72{ }^{\circ} \mathrm{C}$, followed by a final 60 seconds extension at $60{ }^{\circ} \mathrm{C}$ ) were used to quantify each gene of interest (Table 1). Results were quantitatively analyzed with the delta delta $\mathrm{Ct}$ method and were reported as relative expression to the calibrator after normalization of the target transcript to the endogenous control.

Table 1. List of primers used for quantitative real-time PCR analysis

\begin{tabular}{|c|c|c|c|}
\hline Gene Name & $\begin{array}{l}\text { Gene bank accession } \\
\text { number }\end{array}$ & Primer sequence & $\begin{array}{l}\text { Fragment size } \\
(\mathrm{bp})\end{array}$ \\
\hline TFAM & NM_001034016 & $\begin{array}{l}\text { F: 5'-CTGGTCAGTGCTTTGTCTGC-3' } \\
\text { R: 5'-CTAAAGGGATAGCGCAGTCG-3' }\end{array}$ & 128 \\
\hline SOD2 & NM_201527 & $\begin{array}{l}\text { F: 5'-GTGATCAACTGGGAGAATGT-3', } \\
\text { R: 5'-AAGCCACACTCAGAAACACT-3' }\end{array}$ & 163 \\
\hline GAPDH & NM_001034034.2 & $\begin{array}{l}\text { F: 5'- AGGTCGGAGTGAACGGATTC -3, } \\
\text { R: 5'- GGAAGATGGTGATGGCCTTT -3' }\end{array}$ & 219 \\
\hline CPT2 & NM_001045889 & $\begin{array}{l}\text { F: 5'-CCGAGTATAATGACCAGCTC-3' } \\
\text { R: 5'-GCGTATGAATCTCTTGAAGG-3' }\end{array}$ & 152 \\
\hline SREBP1 & NM_001113302 & $\begin{array}{l}\text { F: 5'-CCGTTTCTTCGTGGATGG-3' } \\
\text { R: 5'-ATGCTGGAGCTGATGGAG-3' }\end{array}$ & 264 \\
\hline $\mathrm{TNF} \alpha$ & AF011927 & $\begin{array}{l}\text { F: 5'-GTGAAGTCGCTCAGTCGTGC-3', } \\
\text { R: 5'-TCTACAAGGCGGGAGACCTG-3', }\end{array}$ & 170 \\
\hline NFE2L2 & NM_001011678 & $\begin{array}{l}\text { F: 5'-TAAAACAGCAGTGGCTACCT-3' } \\
\text { R :5'-GAGACATTCCCGTTTGTAGA-3' }\end{array}$ & 159 \\
\hline
\end{tabular}

PCR (polymerase chain reaction) bp (base pair), F (Forward), R (Reverse) 


\section{Data analysis:}

The data produced from the evaluation of gene expression profile from the three animals was analyzed using the General Linear Model procedure (SAS Institute Inc., 2011). The analysis was done to test the effect of stages of CL on the expression of two genes by the use of the following model: $Y_{\mathrm{ij}}=\mu$ $+\mathrm{C}_{\mathrm{i}}+\mathrm{e}_{\mathrm{ij}} \cdot \mathrm{Y}_{\mathrm{ij}}=$ Measured trait, $\mu=$ Overall mean, $\mathrm{C}_{\mathrm{i}}=$ Stages of $\mathrm{CL}$, and $\mathrm{e}_{\mathrm{ij}}=$ Experimental error. The mean values were compared for statistical significance using Duncan's range test (Duncan, 1955). Differences were considered statistically significant at $P \leq 0.05$.

\section{RESULTS}

Expression profile of SOD2 (Figure 1), TFAM (Figure 2) and CPT2 (Figure 3) increased significantly $(\mathrm{P} \leq 0.000)$ in static phase compared to growing and regression ones. Meanwhile, the expression of SOD2 and TFAM genes was higher insignificantly during growth phase than regression phase. However, the transcriptional profile of CPT2 gene was significantly higher during growth phase than regression phase. Meanwhile, the transcript abundance of SREBP1 (Figure 4) increased $(\mathrm{P} \leq 0.000)$ at static phase while it was at minimum profile during regression phase of CL. The expression profile of NFE2L2 (Figure 5) was not significantly different among all stages of $\mathrm{CL}$ development, however; it reached the highest expression during static phase. On the other hand, relative transcript abundance of TNF $\alpha$ (Figure 6) was higher $(\mathrm{P} \leq 0.000)$ at regression phase than growth and static phases.

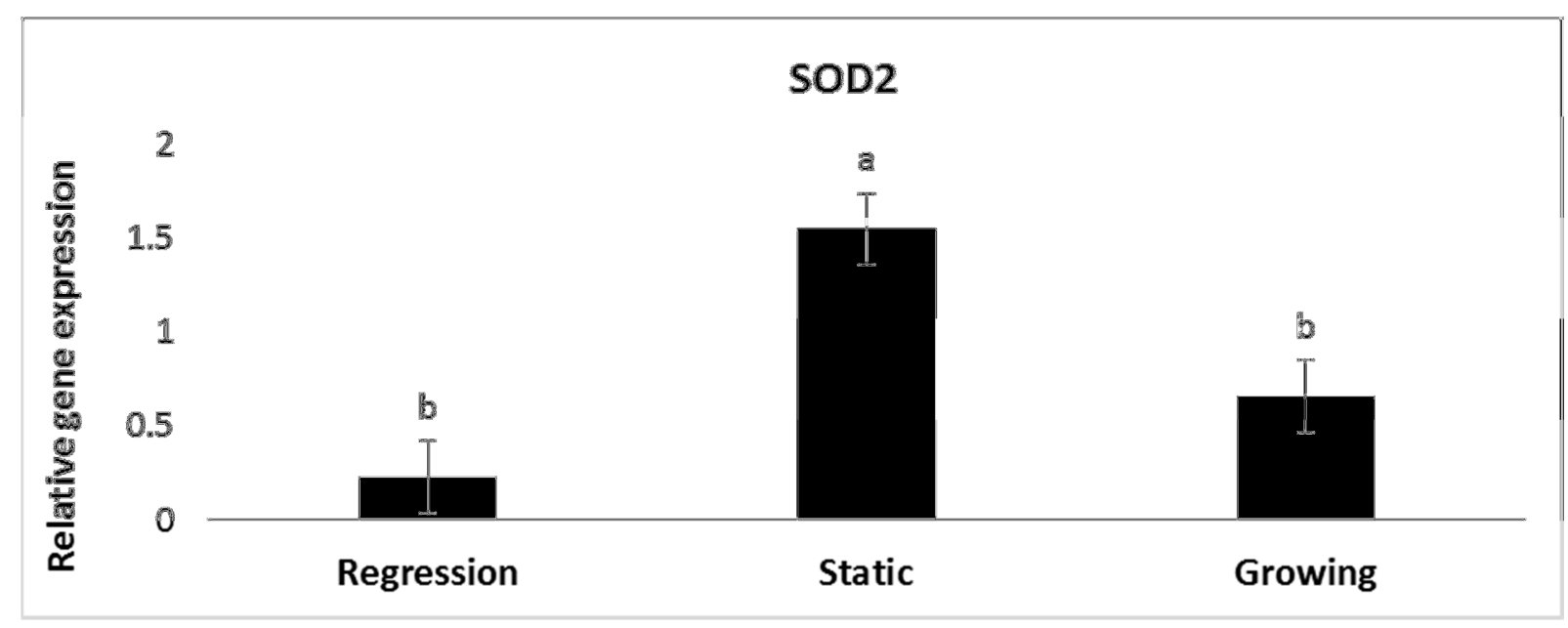

Figure 1. Transcriptional abundance of SOD2 in different developmental phases of cyclic Egyptian buffalo's corpus luteum

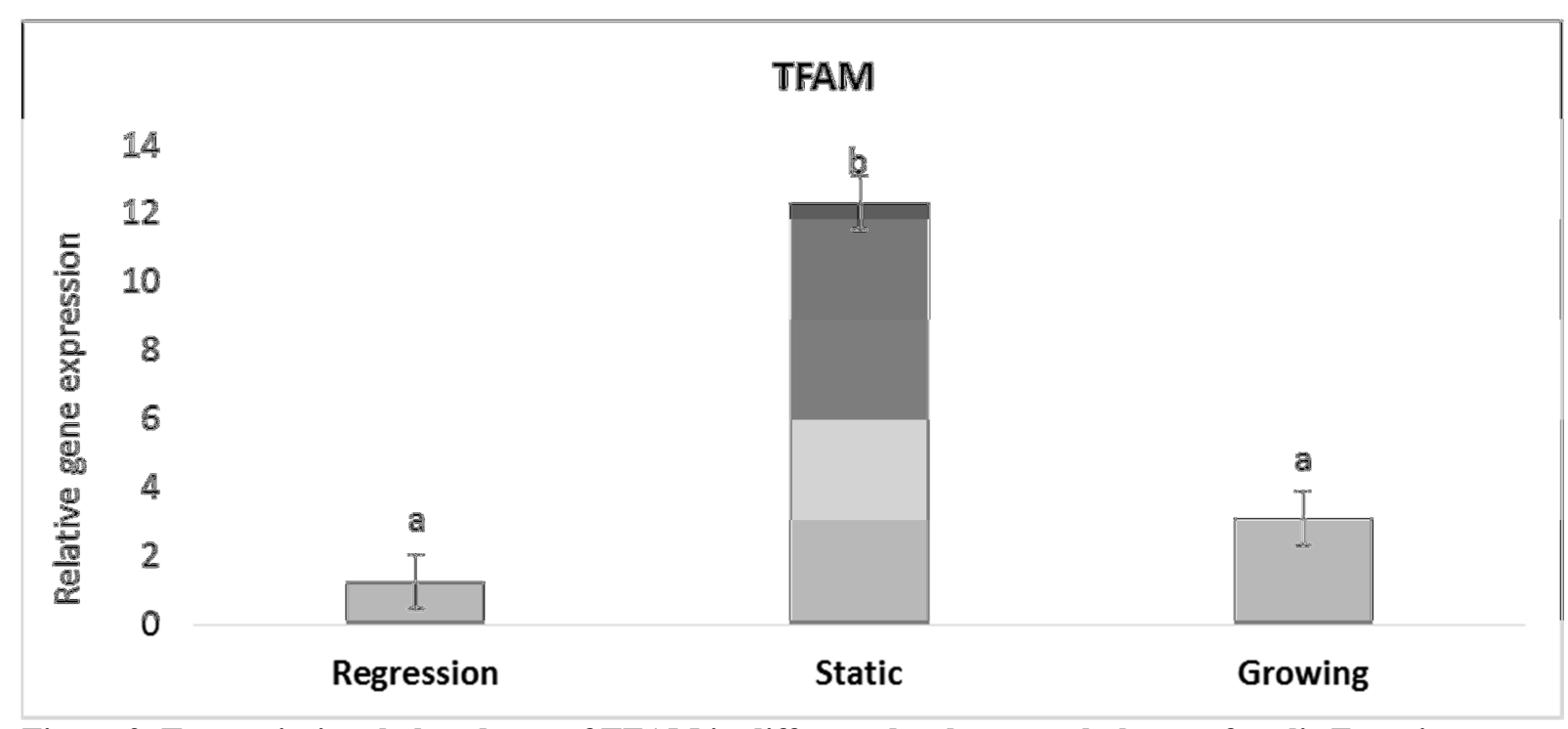

Figure 2. Transcriptional abundance of TFAM in different developmental phases of cyclic Egyptian buffalo's corpus luteum. 


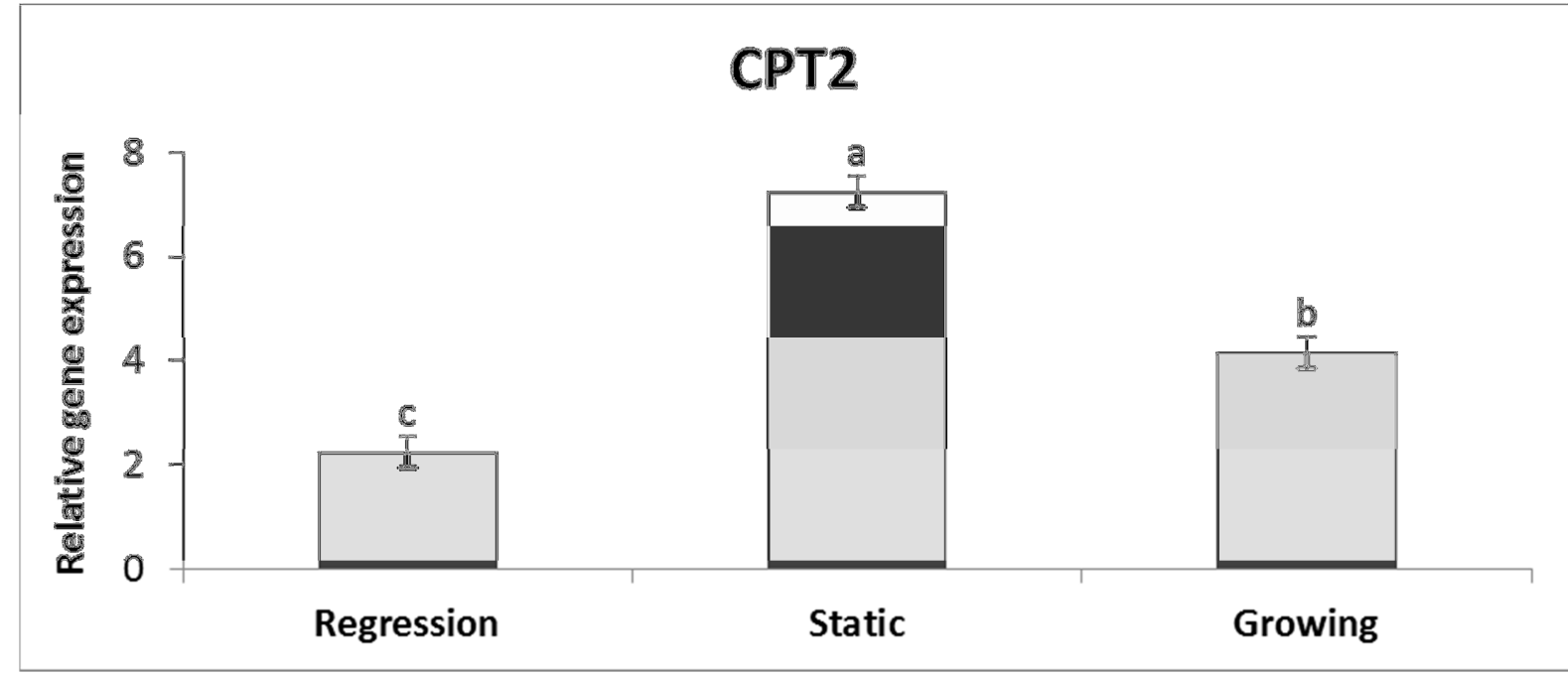

Figure 3. Transcriptional abundance of CPT2 in different developmental phases of cyclic Egyptian buffalo's corpus luteum.

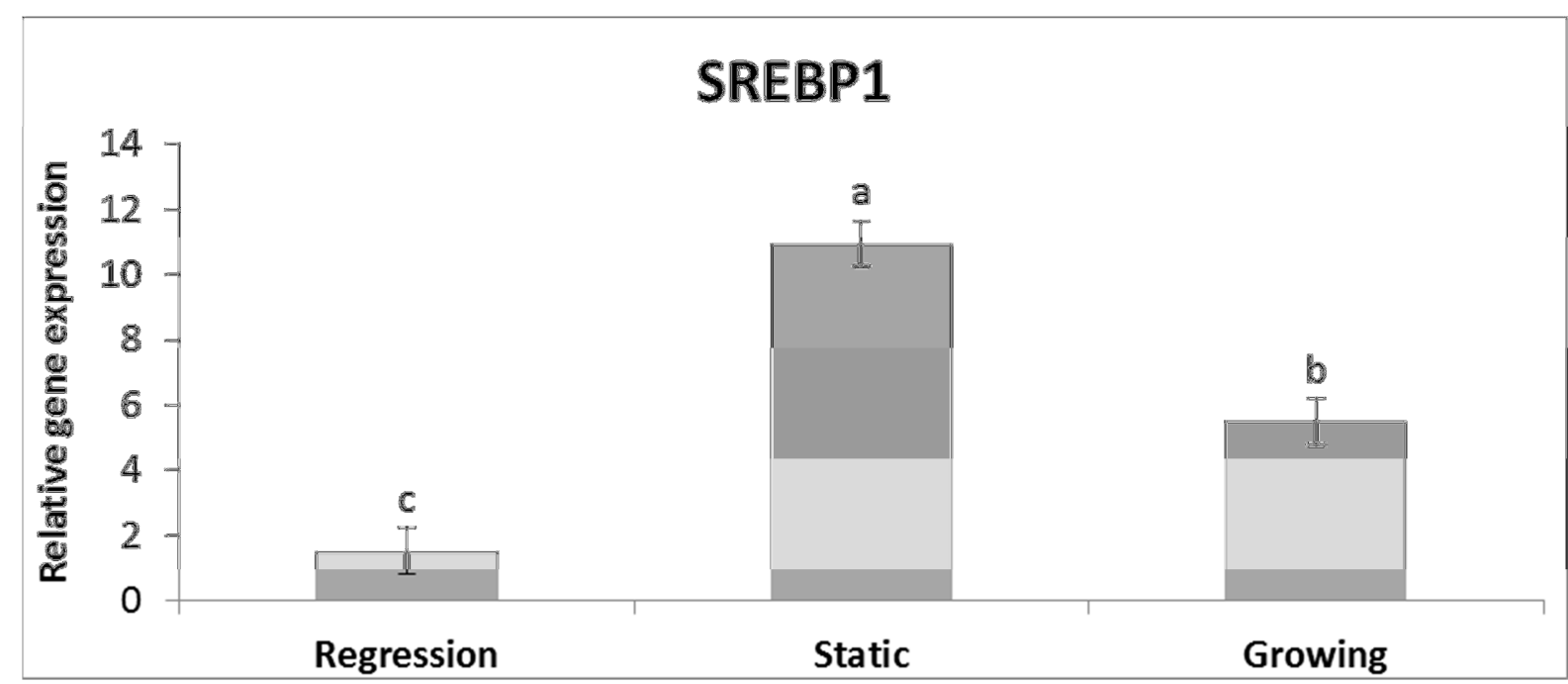

Figure 4. Transcriptional abundance of SREBP1 in different developmental phases of cyclic Egyptian buffalo's corpus luteum.

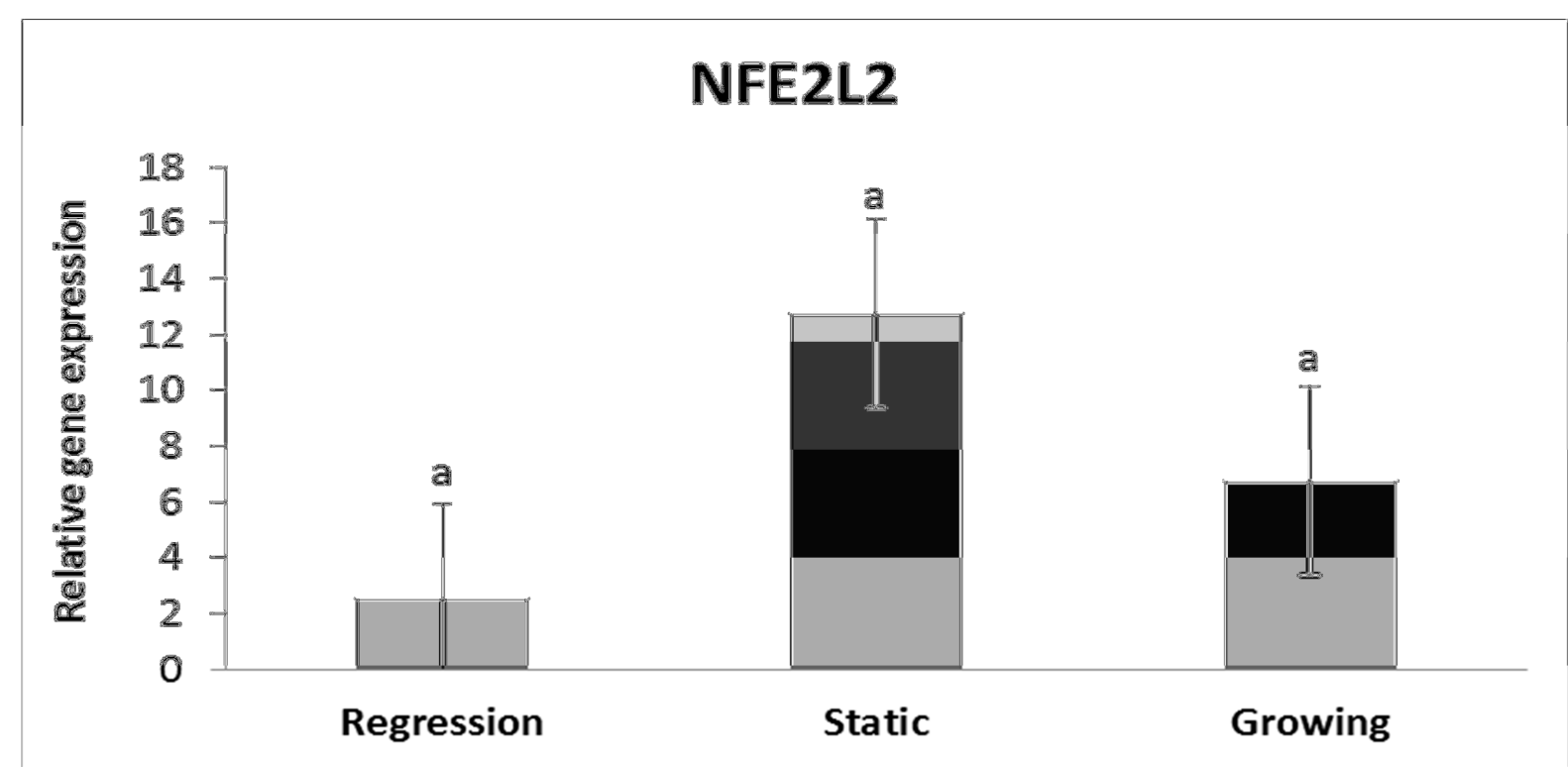

Figure 5. Transcriptional abundance of NFE2L2 in different developmental phases of cyclic Egyptian buffalo's corpus luteum. 


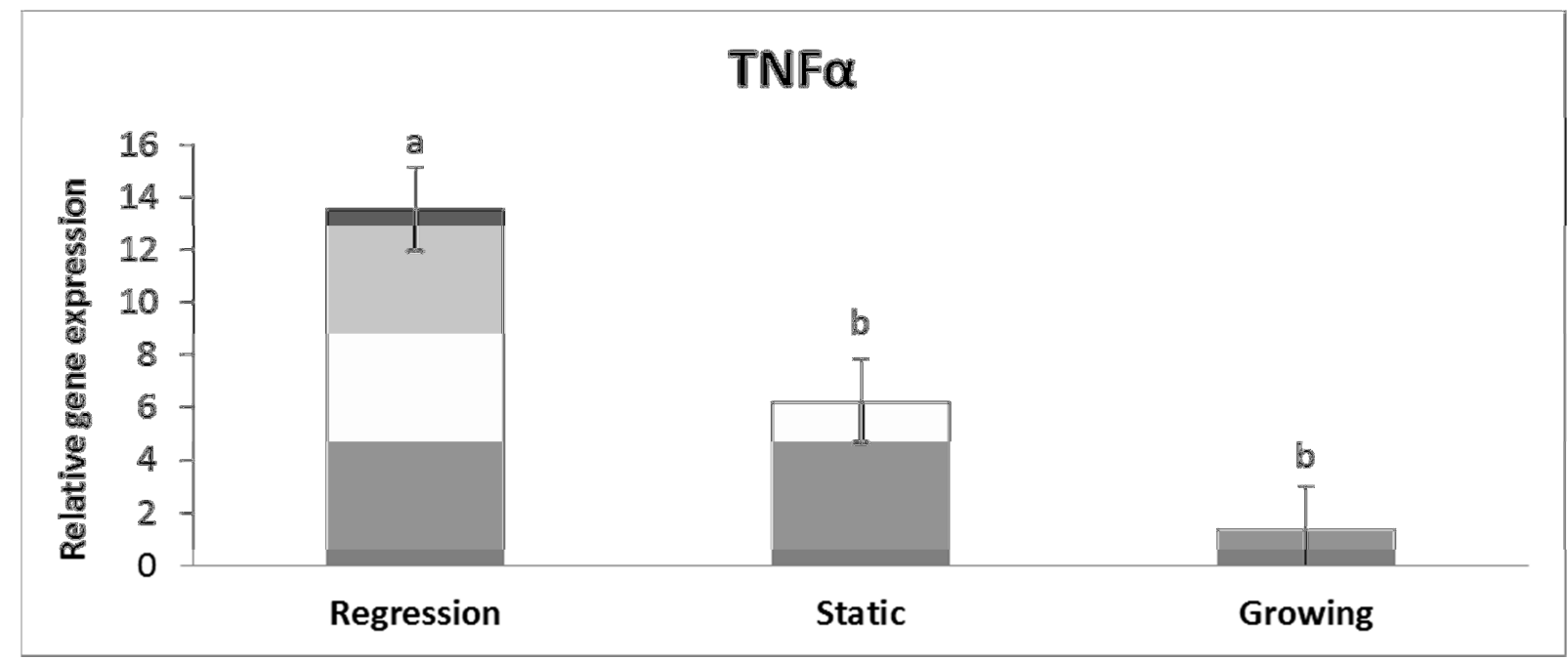

Figure 6. Transcriptional abundance of TNF $\alpha$ in different developmental phases of cyclic Egyptian buffalo's corpus luteum.

\section{DISCUSSION}

Mitochondria have intrinsic functions during ovarian follicle development and granulosa cells luteinization. Progesterone synthesis started inside the mitochondria and finally produced in the endoplasmic reticulum of lutein cells (Niswender et al., 2000). Moreover, mitochondrial transcripts represented approximately $14 \%$ of overall expressed sheep ovary transcriptome (Pokharel et al., 2018) which implied a high-energy demand tissue. Consistent with this idea, results of the current study revealed up-regulation of three mitochondrial transcripts (SOD2, TFAM and CPT2) in static compared to both growing and regressed phases of CL development. In mouse, Foyouzi et al. (2005) found that mRNA for all superoxide dismutase (SOD) enzymes (SOD1, SOD2, and SOD3) expressed in the CL. In addition, SOD2 was the most highly expressed gene in CL (Foyouzi et al., 2005). Kawaguchi et al. (2013) indicated that LH could increase the level of both mRNA protein of SOD1 and SOD2 in bovine CL, which reached the highest expression in the mid-luteal phase. The up-regulation of these two antioxidant enzymes (SOD1, SOD2) is crucial for sustaining cell viability and maintaining $\mathrm{CL}$ function during the luteal phase. Indeed, luteal cells generate oxygen radical species (ROS) as a result of normal cellular metabolism, which has been linked with decreased progesterone production and cell death (Riley et al., 1991). Thus, up-regulation of SOD2 might increase the ability of cells to neutralize ROS. On the other hand, the reduced expression of SOD2, TFAM and CPT2 in coincidence with the regressed phase could be explained by the reduction in the relative volume of mitochondria in the lutein cells during luteolysis process of CL (Pivko et al., 2016). It is known that $\beta$ oxidation of fatty acids depends on the activity of two key enzymes (CPT1B and CPT2) residing in outer and inner mitochondrial membranes (SuttonMcDowall et al., 2012).
The process of steroidogenesis in CL depends mainly on the supply of cholesterol as required precursor from intracellular biosynthesis and extracellular sources. Sterol regulatory elementbinding proteins (SREBP) regulate cholesterol (Hua et al., 1993) and fatty acids (Ye and DeBose-Boyd 2011) at intracellular level.

In the process of CL regression, there is a decline in steroidogenesis coupled with reduction of SREBP2 activity (Rennert et al., 1990 and $\mathrm{Xu}$ et al., 2018). Obtained results of higher expression of SREBP1 during static than both growing and regression phases revealed a possible action of SREBP1 in supporting $\mathrm{P}_{4}$ synthesis and secretion by luteal cells during static phase. Similarly, high expression of PAPP- $\alpha$ as lipid candidate gene was detected in CL of buffalo ovary as compared to corpus albicans (Nayan et al., 2013).

The tumor necrosis factor alpha $(\mathrm{TNF} \alpha)$ is one of the apoptotic signals, which interact with certain cell surface receptors that induce cell death (Nagata, 1997). In accordance, the results of the current investigation revealed higher relative transcript abundance of $\mathrm{TNF} \alpha$ at regression phase than growth and static ones of CL development. In 1995, Shaw and Britt observed that TNF $\alpha$ is released during both spontaneous and PGF2aa induced luteolysis of bovine CL. This also supports the idea that TNF $\alpha$ regulates $C L$ regression via up-regulating its specific receptors (TNFR type-I) during bovine CL luteolysis (Sakumoto et al., 2014 and Neuvians et al., 2004). Moreover, Friedman et al. (2000) suggested that, the tumor necrosis factor $\alpha(\mathrm{TNF} \alpha)$ which induced programmed cell death during structural luteolysis is mediated by its type I receptor (TNFR I), affecting endothelial cells, and then the decline in P40 Preceding structural luteolysis, is a prerequisite for the initiation of apoptosis in endothelial cells. Furthermore, TNF $\alpha$ induces synthesis and release of endothelin 1 (EDN1) from endothelial cells that may induce CL regression (Okuda et al., 1999 and Friedman et al., 2000). Therefore, some researchers (Meidan et al., 1999 and Meidan et al., 2005) have 
suggested that EDN1 is activated and subsequently regulating the structural regression of $\mathrm{CL}$ by promoting migration of leucocyte and stimulating release cytokines such as TNF- $\alpha$ from macrophages.

On the other hand, the expression of two genes (SOD2 and NFE2L2) that involved in cellular defense mechanism against any stress signals increased during static phase compared with growing and regression phases of CL cyclic changes. Because of normal metabolism, cells generate oxygen radical species and the luteal cells increased production of ROS that has been linked with reduced secretion of $\mathrm{P}_{4}$ and apoptosis of its cells (Riley et al., 1991 and Foyouzi et al., 2005). As the mRNA for all SOD enzymes (SOD1, SOD2 and SOD3) expressed in CL of mice being moreover, SOD2 the most highly expressed gene (Foyouzi et al. 2005). Therefore, an explanation of higher expression of NFE2L2 and SOD2 genes is based on the highlighted crucial role of these genes in defense mechanism against oxidative stress as a recent study showed that downregulation of NFE2L2 expression has resulted in increased ROS level, reduced mitochondrial activity and cellular proliferation (Khadrawy et al., 2019). Interestingly, $P_{4}$ profile during the luteal phase was positively correlated with the activity of SOD1. Reduction in SOD1 during CL regression was accompanied by increased ROS levels (Behrman et al., 2001). Kawaguchi et al. (2013) observed increasing expression of the protein and mRNA levels of both SOD1 and SOD2 in the bovine CL reached the highest expression profile in the midluteal phase as a result of LH induction.

In conclusion, the profile of genes regulating mitochondrial activity, lipid metabolism, proinflammatory and stress response was coupled with morphological and biological changes of corpus luteum during estrous cycle of Egyptian buffaloes.

\section{REFERENCES}

Ambrose, J.D., R.S. Manik, S. K. Singla and M.L. Madan, 1993. A simplified laparoscopy technique for repeated ovarian observation in the water buffalo (Bubalus bubalis). Theriogenology, 40: 487-496.

Barkawi, A.H., Y.M. Hafez, S.A. Ibrahim, A.K. ElAsheeri and N. Ghanem, 2002. Progesterone profile in relation to corpus luteum development throughout the normal estrous cycle of Egyptian buffaloes. Egyptian Journal of Animal Production 39, 87-94.

Behrman, H. R., P. H. Kodaman, S. L. Preston and S. Gao, 2001 "Oxidative stress and the ovary," Journal of the Society for Gynecologic Investigation, vol. 8, pp. S40-S42.

Duncan, D.B., 1955. Multiple range and multiple F tests. Biometrics 11, 1-42.

Fadel, M.S., 2000. Uses of ultrasonography in monitoring the reproductive pattern in some farm animals. Ph.D Thesis, Fac. of Vet. Med., Cairo Univ., Giza, Egypt.
Foyouzi, N., Z. Cai, Y. Sugimoto and C. Stocco, 2005. Changes in the Expression of Steroidogenic and Antioxidant Genes in the Mouse Corpus Luteum During Luteolysis Biol Reprod. May;72 (5):1134-41.

Friedman, A., S. Weiss, N. Levy and R. Meidan, 2000. Role of tumor necrosis factor $\square$ and its type I receptor in luteal regression introduction of programmed cell death in bovine corpus luteumderived endothelial cells. Biology of Reproduction, 63, 1905-1912.

Hua, X., C. Yokoyama, J. Wu, M.R. Briggs, M.S. Brown, J.L. Goldstein and X. Wang, 1993. SREBP-2, a second basic-helix-loop-helixleucine zipper protein that stimulates transcription by binding to a sterol regulatory element. Proc Natl Acad Sci U S A. 90:11603-11607.

Ireland, J.J., R.L. Muphee and P.B. Coulso, 1980. Accuracy of predicting stages of bovine estrous cycle by gross appearance of corpus luteum. Journal of Dairy Science, 63: 155- 160.

Jainudeen, M.R., and E.S.E. Hafez, 1993. Cattle and Buffalo. In: Reproduction in Farm Animals, by E.S.E. Hafez (ed), Lea \& Febiger, Philadelphia, U.S.A. (Fifth edition).

Kawaguchi, S., R. Sakumoto and K. Okuda, 2013. Induction of the expressions of antioxidant enzymes by luteinizing hormone in the bovine corpus luteum. J Reprod Dev. 59(3):219-24.

Khadrawy, O., S. Gebremedhn, D. Salilew-Wondim, M.O. Taqi, C. Neuhoff, E. Tholen, M. Hoelker, K. Schellander and D. Tesfaye, 2019. Endogenous and Exogenous Modulation of Nrf2 Mediated Oxidative Stress Response in Bovine Granulosa Cells: Potential Implication for Ovarian Function. Int J Mol Sci. Apr 2;20(7). pii: E1635.

Meidan, R., N. Levy, T. Kisliouk, L. Podlovny, M. Rusiansky and E. Klipper, 2005. The yin and yang of corpus luteum-derived endothelial cells: Balancing life and death. Domest Anim Endocrinol 29, 318-328.

Meidan, R., R.A. Milvae, S. Weiss, N. Levy and A. Friedman, 1999. Intra-ovarian regulation of luteolysis. J Reprod Fertil Suppl 54, 217-228.

Mishra, G. K., M. K. Patra, P. A. Sheikh, A. S. Teeli, N. S. Kharayat, M. Karikalan, S. Bag, S. K. Singh, G. K. Das, K. Narayanan and H. Kumar, 2018. Functional Characterization of Corpus Luteum and its Association with Peripheral Progesterone Profile at Different Stages of Estrous Cycle in the Buffalo. Journal of Animal Research: v.8 n.3, p. 507-512. June.

Nagata, S., 1997. Apoptosis by death factor. Cell 88, 355-365.

Nayan, V., B. Anuradha and S. Dheer, 2013. PAPP$A$ in Indian Water Buffalo (Bubalus bubalis) Ovary: Phylogeny, Expression, Hormonal Regulation, and Sequence Characterization. Agric Res., 2(2):153-165. 
Neuvians, T.P., D. Schams, B. Berisha and M.W. Pfaffl, 2004. Involvement of pro-inflammatory cytokines, mediators of inflammation, and basic fibroblast growth factor in PGF2ainduced luteolysis in bovine corpus luteum. Biol Reprod 70, 473-480.

Niswender, G.D., J. L. Juengel, P. J. Silva, M. K. Rollyson and E.W. McIntush, 2000. Mechanisms controlling the fuctions and life span of the corpus luteum. Physiol Rev. Jan; 80(1):1-29.

O’Shea, J. D., R. J. Rodgers and M. J. D’Occhio, 1989. Cellular composition of the cyclic corpus luteum of the cow. J Reprod Fertil, 85: 483-487.

Okuda, K., R. Sakumoto, Y. Uenoyama, B. Berisha, A. Miyamoto and D. Schams, 1999. TNFa receptors in microvascular endothelial cells from bovine corpus luteum. Biol Reprod 61, 10171022.

Pivko J., V.A. Makarevich, E. Kubovičova, J. Rafay and P. Chrenek, 2016. Ultrastructural changes in the cyclic corpus luteum of dairy cows with different body condition. Acta VeterinariaBeograd 2016, 66 (2), 245-256.

Pokharel, K., J. Peippo, M. Honkatukia, A. Seppälä, J. Rautiainen, N. Ghanem, T. M. Hamama, M. A. Crowe, M. Andersson, M. H. Li and J. Kantanen, 2018. Integrated ovarian mRNA and miRNA transcriptome profiling characterizes the genetic basis of prolificacy traits in sheep (Ovis aries). BMC Genomics. 29;19(1):104.

Quintal-Franco, J. A., F. N. Kojima, E. J. Melvin, B. R. Lindsey, E. Zanella, K. E. Fike, M. E. Wehrman, D. T. Clopton and J. E. Kinder, 1999. Corpus luteum development and function in cattle with episodic release of luteinizing hormone pulses inhibited in the follicular and early luteal phases of the estrous cycle. Biol Reprod. Oct;61(4):921-6.
Rennert, H., R. T. Fischer, J. G. Alvarez, J. M. Trzaskos and J. F. Strauss, 1990. 3rd. Generation of regulatory oxysterols: 26hydroxylat ion of cholesterol by ovarian mitochondria. Endocrinology. Aug;127(2):738-46.

Riley, J. C., and H. R. Behrman, 1991. In vivo generation of hydrogen peroxide in the rat corpus luteum during luteolysis. Endocrinology. 128: 1749-1753.

Rozen, S., and H. Skaletsky, 2000. Primer3 on the WWW for general users and for biologist programmers. Methods Mol Biol.132:365-86.

Sakumoto, R., K. G. Hayashi and T. Takahashi, 2014. Different expression of PGE synthase, PGF receptor, TNF, Fas and oxytocin in the bovine corpus luteum of the estrous cycle and pregnancy. Reprod Biol. Apr;14(2):115-21.

SAS Institute Inc., 2011. SAS/STAT ${ }^{\circledR} 9.3$ User's Guide. SAS Inst. Inc., Cary, NC, USA.

Shaw, D. W., and J. H. Britt, 1995. Concentrations of TNFa and P4 within the bovine corpus luteum sampled by continuousflow microdialysis during luteolysis in vivo. Biol Reprod 53, 847-854.

Sutton-McDowall, M. L., D. Feil, R. L. Robker, J. G. Thompson and K. R. Dunning, 2012. Utilization of endogenous fatty acid stores for energy production in bovine preimplantation embryos. Theriogenology. 77: 1632-41.

Xu, Y., S. M. Hutchison, J. J. Hernández-Ledezma, and R. L. Bogan, 2018. Increased 27hydroxycholesterol production during luteolysis may mediate the progressive decline in progesterone secretion. Mol Hum Reprod. Jan $1 ; 24(1): 2-13$.

Ye, J., and R. A. DeBose-Boyd, 2011. Regulation of Cholesterol and Fatty Acid Synthesis. Cold Spring Harb Perspect Biol. Jul 1;3(7).

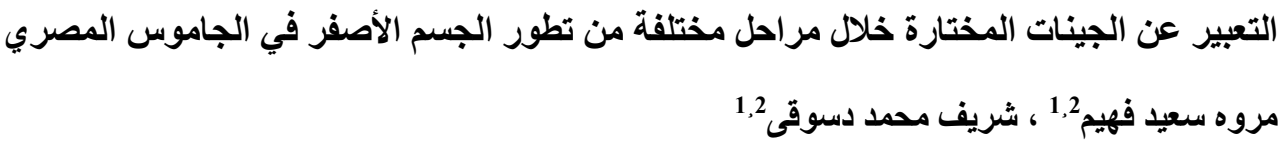

ـ ـ قسم الإنتاج الحيوانس، كلية الزراعة، جامعة القاهرة، r ـ مجدع المعامل البشثية، كلية الزراعة، جامعة القاهرة

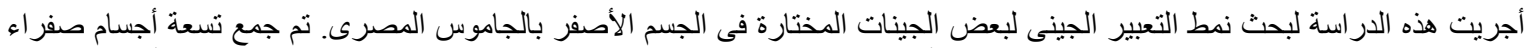

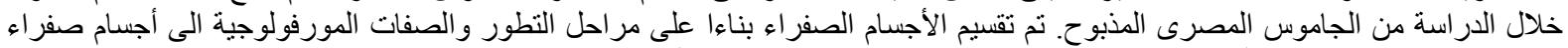

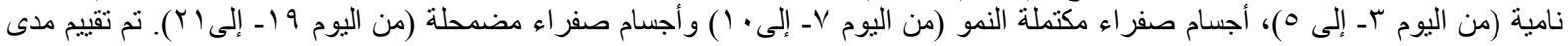

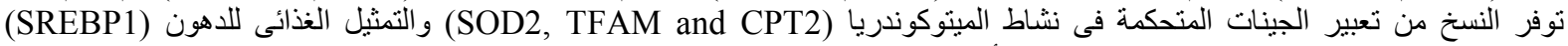

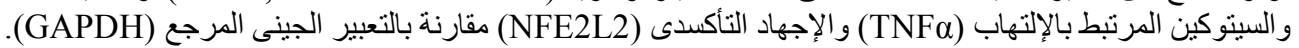

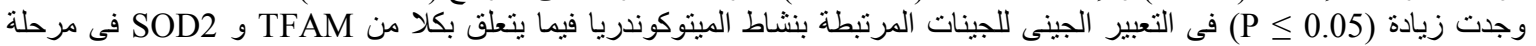

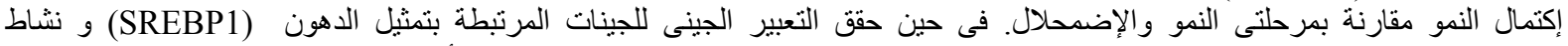

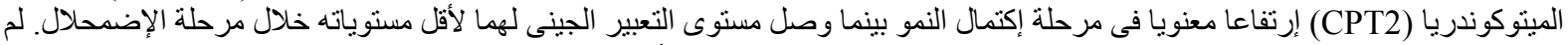

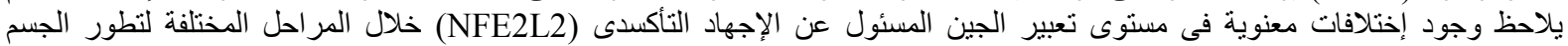

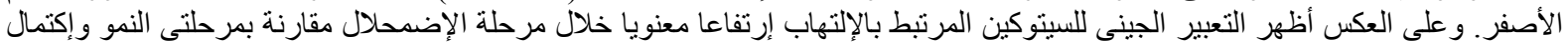

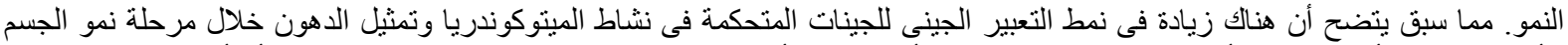

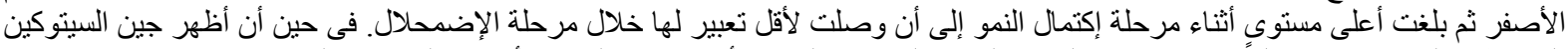

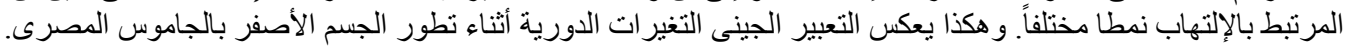

